\title{
Pengembangan Instrumen Tes Siswa Tingkat Sekolah Dasar Kabupaten Kuningan
}

\author{
${ }^{1}$ Syamsul Alam, ${ }^{2}$ Muhammad Japar, ${ }^{3}$ Muhammad Nur Ashar Asnur \\ 1,2,3 Universitas Negeri Jakarta
}

\author{
Email: syamsoelalam91@gmail.com, mjapar@unj.ac.id, ashar@unj.ac.id
}

\begin{abstract}
Abstrak
Penelitian ini bertujuan untuk menghasilkan soal-soal yang valid dan praktis sesuai dengan konsep Taksonomi Bloom. Penelitian ini meurpakan penelitian pengembangan instrumen yang terdiri dari tujuh langkah (1) menyusun spesifikasi tes (2) menulis soal tes (3) menelaah soal tes (4) memperbaiki tes (5) melakukan uji coba tes (6) menganalisis butir soal tes (7) menafsirkan hasil tes. Uji coba instrumen dilakukan di SD Negeri Pajambon Kabupaten Kuningan, pemilihan subjek coba dilakukan dengan teknik sampel acak sederhana. Subjek penelitian ini adalah siswa kelas II SD Negeri Pajambon Kabupaten Kuningan sebanyak 20 siswa. Pengujian kualitas instrumen menggunakan bantuan software excel. Validitas isi instrumen diperoleh dari penilaian pakar dengan menggunakan lembar validasi. Reliabilitas tes dianalisis menggunakan persamaan Flanagan. Haisl penelitian ini adalah instrumen tes yang dikembangkan memenuhi keriteria yang baik adalah dari hasil analisis tersebut diperoleh bahwa semua soal pilihan ganda valid dengan nilai sebesar 0,81 dan soal uraian valid dengan nilai sebesar 2.04 yang berarti memiliki reliabilitas tinggi. Dari hasil ini dapat disimpulkan bahwa soal yang dikembangkan valid secara kualitatif, valid secara kuantitatif dan memiliki kriteria reliabilitas yang tinggi.
\end{abstract}

Kata Kunci: instrument tes, sekolah dasar, pengembangan instrumen

\begin{abstract}
This study aims to produce valid and practical questions in accordance with Bloom's Taxonomy concept. This research is an instrument development research consisting of seven steps: (1) compiling test specifications (2) writing test questions (3) examining test questions (4) improving tests (5) conducting test tests (6) analyzing test items (7) interpreting test results. The instrument trial was conducted at Pajambon Public Elementary School, Kuningan Regency, the selection of trial subjects was carried out using a simple random sampling technique. The subjects of this study were class II students of SD Negeri Pajambon Kuningan Regency as many as 20 students. Instrument quality testing using the help of excel software. The content validity of the instrument was obtained from expert judgment using a validation sheet. Test reliability was analyzed using the Flanagan equation. The result of this research is that the test instruments developed to meet good criteria are from the results of the analysis that all multiple choice questions are valid with a value of 0.81 and valid description questions with a value of 2.04 which means it has high reliability. These results can be concluded that the questions developed are qualitatively valid, quantitatively valid and have high reliability criteria.
\end{abstract}

Keywords: test instrument, elementary school, instrument development 


\section{PENDAHULUAN}

Pendidikan di sekolah dasar merupakan hal dasar pada terselenggaranya kegiatan proses belajar mengajar selanjutnya baik pada jenjang menengah ke atas mau pun pada jenjang perguruan tinggi. Keberhasilan atau tidaknya pada pencapaian proses pendidikan formal bergantung kepada bagaimana proses belajar mengajar yang dialami peserta didik pada jenjang di sekolah dasar. Pernyataan tersebut sesuai dengan isi Undang-Undang Republik Indonesia Nomor 20 Pasal 1 tahun 2003 tentang Sistem Pendidikan Nasional bahwa, Pendidikan adalah usaha sadar dan terencana untuk mewujudkan suasana belajar dan proses pembelajaran agar peserta didik secara aktif mengembangkan potensi dirinya untuk memiliki kekuatan spiritual keagamaan, pengendalian diri, kepribadian, kecerdasan, akhlak mulia, serta keterampilan yang diperlukan dirinya, masyarakat, bangsa dan negara.

Sehubungan dengan pencapain tujuan pendidikan nasional, telah dilakukan berbagai upaya oleh pemerintah untuk meningkatkan mutu pendidikan antara lain diadakan perubahan dan penyesuaian kurikulum di semua jenjang pendidikan, perbaikan mutu pendidikan seperti penataran guru-guru, pengadaan buku paket dan penambahan sarana dan prasarana untuk kegiatan belajar mengajar di kelas termasuk pengelolahan proses pembelajaran setiap mata pelajar.

Pengelolahan proses pembelajaran guru dituntut untuk mampu mengembangkan instrumen penilaian dan evaluasi proses dan hasil belajar. Melalui evaluasi kita dapat mengetahui dan mengambil keputusan dari hasil pengukuran yang dilakukan. Evaluasi pembelajaran merupakan proses penentuan nilai sesuatu berdasarkan kriteria untuk memperoleh informasi atau data dari tingkat kemampuan dan pemahaman siswa baik dari segi kognitif, psikomotor, maupun afektif nantinya akan digunakan untuk memperbaiki hal-hal yang memang perlu diperbaiki pada proses pembelajaran. Menurut Zainal Arifin (2011:5) menjelaskan bahwa, evaluasai adalah suatu proses untuk mengetahui kualitas sesuatu, baik tentang segi nilai mau pun arti berdasarkan pertimbangan dan kriteria tertentu dalam rangka pengambilan keputusan.

Hal yang sangat mempengaruhi kualitas penilaian dan evaluasi proses dan hasil belajar adalah instrumen yang akan digunakan. Instrumen merupakan alat yang digunakan untuk mengukur kegiatan evaluasi pembelajaran. Salah satunya adalah tes. Tes yang digunakan di sekolah biasanya untuk mengukur tingkat kemapuan atau prestasi siswa dalam bidang kognitif, seperti pengetahuan, pemahaman, analisis, sintesis, dan evaluasi. Sebagaimana yang disampaikan Purwanto (2013:56) bahwa, tes merupakan alat atau instrumen untuk mengumpulkan data dari hasil respons peserta 
didik atas pertanyaan dalam instrumen yang dimana tugas tersebut harus dijawab atau kerjakan oleh peserta didik.

Dalam membuat tes, harus dibuat secara logis dan rasional mengenai pokok-pokok materi apa saja yang patut ditanyakan sebagai bahan pengetahuan penting untuk diketahui dan dipahami oleh peserta didik. Bukan hanya itu, tes yang dibuat oleh guru perlu memperhatikan tingkat kesukaran itemnya yang didasarkan sifat atau karakteristik siswa. tes yang dibuat juga perlu diuji cobakan pada kelompok besar.

Dari hasil uji instrumen tersebut dilakukan validitas dan reliabilitas agar dapat dijadikan alat ukur yang betul-betul berkualitas dan sahih sesuai kemapuan siswa. Validitas berhubungan dengan kemampuan dalam mengukur ketepatan sesuatu yang ingin diukur. Tes yang valid adalah tes yang mengukur dengan tepat keadaan yang ingin diukur. Sebalikanya, tes dikatakan tidak valid bila digunakan untuk mengukur suatu keadaan yang tidak tepat diukur dengan tes tersebut. Sebagaimana yang dijelaskan Anastasi dan Urbina (1997) bahwa validitas berhubungan dengan tes apa yang mesti diukurnya dan seberapa baik melakukannya.

Begitu pun dengan uji reliabilitasnya yang berhubunga pada tingkat akurasi tes apa yang mesti diukur. Menurut Thorndike dan Hagen (1977) reliabilitas berhubungan pada akurasi instrumen atau tes untuk menghasilkan kecermatan hasil ukur. Jadi, Syarat yang harus dipenuhi untuk menjadi alat ukur hasil belajar yang baik berhubungan dengan validitas dan reliabilitas. sehingga Tes yang memenuhi syarat alat ukur yang baik dapat menghasilkan hasil ukur yang akurat.

Namun, kebanyakan guru mengabaikan hal tersebut yang hanya mengambil dari potonganpotongan materi dari buku dan bahkan hanya mengambil pertanyaan yang ada pada buku paket saja. Tanpa memikir apa yang patut dan seharusnya yang ditanyakan untuk bahan pengetahuan penting yang harus diketahui dan dipahami oleh peserta didiknya. Begitu juga tetang tingkat kesukaran itemnya yang tidak didasarka sifat dan karakteristik peserta didiknya.

Terdapat beberapa alasan sehingga penulis melakukan pengembangan Instrumen tes di kelas II sekolah dasar Kabupaten Kuningan. Bagaimana guru membuat sebuah instrumen yang baik dalam melakukan proses evaluasi pembelajaran siswa. Dengan demikian, hasil uji coba instrumen yang dilakukan dapat memberikan manfaat kepada guru dan siswa. bukan hanya di kabupaten kuningan melainkan seluruh Indonesia. 


\section{METODE PENELITIAN}

Guna menghasilkan instrumen tes yang berkualitas, maka penelitian ini menggunakan model penelitian pengembangan. Prosedur pengembangan yang dilakukan mengacu pada prosedur pengembangan instrumen tes yang dikemukakan oleh Djemari Mardapi (2008: 88) langkah-langkah yang dipakai yakni: (1) menyusun spesifikasi tes (2) menulis soal tes (3) menelaah soal tes (4) memperbaiki tes (5) melakukan uji coba tes (6) menganalisis butir soal tes (7) menafsirkan hasil tes. Ketujuh langkah tersebut dibedakan menjadi dua tahap, yaitu tahap perancangan dan tahap uji coba.

Subjek dalam uji coba instrumen ini adalah siswa kelas II SD Negeri Pajambon Kabupaten Kuningan. Kelas II SD Negeri Pajambon memiliki 2 kelas, yaitu kelas II A dan Kelas II B. Karena seluruh individu yang menjadi anggota populasi memiliki peluang yang sama untuk dijadikan sampel, maka penentuan sampel dilakukan dengan cara pengambilan acak sederhana (simple random sampling) (Sukmadinata, 2004). Sehingga kelas yang terpilih secara acak adalah kelas II A.

Penelitian ini menggunakan instrumen pengumpulan data berupa lembar validasi. Lembar validasi format penelaahan instrumen penilain tes, guna untuk mengetahui ketepatan interpretasi instrumen penilaian tes baik pilihan ganda maupun uraian. Instrumen penilaian tes tersebut digunakan pada saat uji coba.

Penelitian ini menggunakan analisis soal secara kuantitatif. Analisis soal secara kuantitatif adalah proses penelaah butir soal melalui informasi dari jawaban peserta tes guna meningkatkan mutu butir soal yang bersangkutan dengan menggunakan teori klasik. Aspek yang diperhatikan dalam teori klasik adalah tingkat kesukaran butir, daya pembeda dan penyebaran pilihan jawaban (untuk soal bentuk pilihan ganda). Sehingga dalam penelitian ini menggunakan dua aspek penelaahan soal, yaitu tingkat kesukaran soal dan daya pembeda soal ditambah dengan uji reliabilitas instrumen.

\section{HASIL DAN PEMBAHASAN}

\section{Hasil}

Data mengenai proses pengembangan instrumen hasil belajar didapatkan dari tahap perancangan. Tahapan ini terdiri dari empat langkah yaitu: menyusun spesifikasi tes, menulis soal tes, menelaah soal tes, dan memperbaiki tes. Tahap perancangan dilakukan dari tanggal 27 Oktober 2018 sampai 8 November 2018, dengan rincian sebagai berikut:

Pertama, menyusun spesifikasi tes terdapat 3 tahap. Spesifikasi tes berisi uraian yang menunjukan keseluruhan karakteristik yang harus dimiliki suatu tes. Penyusunan spesifikasi tes 
mencakup kegiatan berikut: pertama, menentukan tujuan tes. Kedua, menyusun kisi-kisi tes. Setelah proses penentuan tujuan tes, kegiatan berikutnya adalah menyusun kisi-kisi tes. Kisi-kisi yang disusun berdasarkan materi pada Tema 4 Hidup Bersih dan Sehat Subtema 1 Hidup Bersih dan Sehat di Rumah yang terdiri dari empat mata pelajaran yaitu PPKn, Bahasa Indonesia, Matematika. Kisi-kisi tes disajikan dalam bentuk matriks yang berisi beberapa komponen yaitu kompetensi dasar, indikator, teknik penilaian dan bentuk instrumen. Setelah menyusun semua komponen selanjutnya memilih bentuk tes yang sesuai. Ketiga, Memilih bentuk tes. Bentuk tes yang dikembangkan yaitu tes tertulis berbentuk pilihan ganda dan uraian. Pemilihan bentuk tes tersebut berdasarkan pertimbangan bahwa tes tersebut memiliki keunggulan untuk mengukur tes hasil belajar yang kompleks. Sehingga bisa digunakan untuk mengukur kemampuan berfikir tingkat tinggi peserta didik yang sesuai dengan konsep Taksonomi Bloom.

Kedua, menulis soal tes. Setelah penyusunan kisi-kisi soal, langkah selanjutnya adalah menulis butir-butir soal tes. Banyaknya butir soal tes untuk setiap indikator minimal satu untuk setiap butir soal. Penyusunan butir soal disesuaikan dengan tingkatan kognitif yang sesuai dengan Taksonomi Bloom edisi revisi yaitu level Mengingat (C1), memahami (C2), mengaplikasikan (C3), menganalisis (C4), Mengevaluasi (C5), dan mengkreasi (C6). Selain memperhatikan tingkatan berfikir, Taksonomi Bloom edisi revisi jugatidak bisa dilepaskan dari dimensi pengetahuan yang meliputi pengetahuan faktual, konseptual, prosedural dan metakognitif. Kompetensi dasar yang dipilih dalam penelitian ini didasarkan pada Kurikulum 2013. Setelah itu kompetensi dasar dijabarkan kedalam beberapa indikator sesuai dengan level tujuan pembelajaran yang terdapat dalam perjenjangan Taksonomi Bloom edisi revisi. Indikator dijabarkan dalam Tabel 3.2 sebagai berikut:

Tabel 1. Indikator

\begin{tabular}{|c|l|c|}
\hline Mata Pelajaran & \multicolumn{1}{|c|}{ Indikator } & Level \\
\hline & $\begin{array}{l}\text { 3.4.1 mengidentifikasi berbagai kegiatan di } \\
\text { rumah yang menunjukkan persatuan dalam } \\
\text { keberagaman secara tepat. }\end{array}$ & \\
\cline { 2 - 3 } & $\begin{array}{l}\text { 3.4.2 menyebutkan contoh persatuan dalam } \\
\text { keberagaman di rumah secara benar. }\end{array}$ & C3 \\
\cline { 2 - 4 } PPKn & $\begin{array}{l}\text { 3.4.3 menjelaskan manfaat hidup bersatu } \\
\text { dalam keberagaman di rumah secara benar. }\end{array}$ & C2 \\
\cline { 2 - 4 } & $\begin{array}{l}\text { 3.4.4 menjelaskan akibat dari hidup tidak } \\
\text { bersatu dalam keberagaman di rumah secara } \\
\text { benar. }\end{array}$ & C2 \\
\hline
\end{tabular}




\begin{tabular}{|c|c|c|}
\hline \multirow{5}{*}{ Bahasa Indonesia } & $\begin{array}{l}\text { 3.4.1 menyebutkan isi teks yang dibacakan } \\
\text { berkaitan dengan lingkungan rehat } \\
\text { menggunakan bahasa lisan (dapat dibantu } \\
\text { dengan kosakata bahasa daerah untuk } \\
\text { membantu pemahaman) dengan benar. }\end{array}$ & $\mathrm{C} 1$ \\
\hline & $\begin{array}{l}\text { 3.4.2 menyebutkan contoh yang berkaitan } \\
\text { dengan lingkungan sehat dan lingkungan tidak } \\
\text { sehat dengantepat. }\end{array}$ & $\mathrm{C} 1$ \\
\hline & $\begin{array}{l}\text { 3.4.3 menemukan kosakata yang berkaitan } \\
\text { dengan lingkungan sehat berdasarkan gambar } \\
\text { dengan benar. }\end{array}$ & $\mathrm{C} 3$ \\
\hline & $\begin{array}{l}\text { 3.4.4 menjelaskan makna kosakata yang } \\
\text { berkaitan dengan lingkungan sehat dengan } \\
\text { benar. }\end{array}$ & $\mathrm{C} 2$ \\
\hline & $\begin{array}{lcc}\text { 3.4.5 menyebutkan manfaat menjaga } \\
\text { lingkungan dengan benar. }\end{array}$ & $\mathrm{C} 1$ \\
\hline \multirow{3}{*}{ Matematika } & $\begin{array}{l}\text { 3.9.1 menentukan ruas garis yang membatasi } \\
\text { model bangun datar secara benar. }\end{array}$ & C3 \\
\hline & $\begin{array}{l}3.10 .1 \text { mengenal sisi, sudut, dan titik sudut } \\
\text { bangun datar secara benar. }\end{array}$ & $\mathrm{C} 1$ \\
\hline & $\begin{array}{l}3.10 .2 \text { menentukan banyak sisi, sudut, dan titik } \\
\text { sudut bangun datar secara benar. }\end{array}$ & C3 \\
\hline \multirow{2}{*}{ SBdP } & $\begin{array}{l}\text { 3.2.1 menjelaskan panjang dan pendek bunyi } \\
\text { pada lagu anak menggunakan symbol dengan } \\
\text { benar. }\end{array}$ & $\mathrm{C} 2$ \\
\hline & $\begin{array}{l}\text { 3.2.2 menentukan panjang dan pendek bunyi } \\
\text { pada lagu anak menggunakan symbol dengan } \\
\text { benar. }\end{array}$ & C3 \\
\hline
\end{tabular}

Ketiga, menelaah soal tes. Salah satu tahapan untuk menghasilkan tes yang baik adalah dengan melakukan penelaahan tes. Tes yang telah disusun diserahkan pada ahli untuk ditelaah. Kegiatan penelaahan tes dilakukan pada tanggal 19 November 2018 di Universitas Negeri Jakarta dengan melibatkan pakar pendidikan yaitu Dr. Muhammad Japar, M.Si. Penelaahan butir tes didahului dengan penetapan level tes berdasarkan perjenjangan Taksonomi Bloom edisi revisi dan kesesuaian antara instrumen tes tertulis bentuk pilihan ganda dan uraian dengan materi pembelajaran. Selain itu pakar memberikan masukan lain seperti kesesuaian konten, konstruks, dan bahasa dengan konsep Taksonomi Bloom.

Keempat, memperbaiki tes. Setelah proses penelaahan oleh pakar pendidikan, maka selanjutnya instrumen direvisi berdasarkan saran yang telah diberikan. Hasil revisi tersebut diuraikan berdasarkan penjabaran indikator menghasilkan 18 butir soal pilihan ganda dan 8 butir soal uraian. 


\subsection{Analisis Data Hasil Uji Coba 1}

Rekapitulasi koefisien korelasi dan status butir soal :

\begin{tabular}{cccc}
\hline No. & $\mathrm{r}_{\text {hitung }}$ & $\mathrm{r}_{\text {tabel }}$ & Status \\
\hline 1 & 0.556 & 0.444 & Valid \\
\hline 2 & 0.4852 & 0.444 & Valid \\
\hline 3 & 0.4928 & 0.444 & Valid \\
\hline 4 & 0.4507 & 0.444 & Valid \\
\hline 5 & 0.6258 & 0.444 & Valid \\
\hline 6 & 0.4923 & 0.444 & Valid \\
\hline 7 & 0.0585 & 0.444 & Tidak Valid \\
\hline 8 & 0.5749 & 0.444 & Valid \\
\hline 9 & 0.5661 & 0.444 & Valid \\
\hline 10 & 0.5061 & 0.444 & Valid \\
\hline 11 & 0.478 & 0.444 & Valid \\
\hline 12 & 0.5661 & 0.444 & Valid \\
\hline 13 & 0.0619 & 0.444 & Tidak Valid \\
\hline 14 & 0.50611 & 0.444 & Valid \\
\hline 15 & 0.7391 & 0.444 & Valid \\
\hline 16 & 0.1676 & 0.444 & Tidak Valid \\
\hline 17 & 0.5201 & 0.444 & Valid \\
\hline 18 & 0.5061 & 0.444 & Valid \\
\hline
\end{tabular}

Tabel 2. Hasil Validasi Soal Pilihan Ganda

\begin{tabular}{cccc}
\hline No. & $\mathrm{r}_{\text {hitung }}$ & $\mathrm{r}_{\text {tabel }}$ & Status \\
\hline 1 & 0.5488 & 0.444 & Valid \\
\hline 2 & 0.5089 & 0.444 & Valid \\
\hline 3 & 0.5786 & 0.444 & Valid \\
\hline 4 & 0.6271 & 0.444 & Valid \\
\hline 5 & 0.5124 & 0.444 & Valid \\
\hline 6 & 0.5843 & 0.444 & Valid \\
\hline 7 & 0.6022 & 0.444 & Valid \\
\hline 8 & 0.4624 & 0.444 & Valid \\
\hline
\end{tabular}

Tabel 2. Hasil Validasi Butir Soal Uraian

Sedangkan untuk koefisien reliabilitas soal pilihan ganda diperoleh nilai sebesar 0.81 sedangkan soal uraian diperoleh nilai sebesar 2.04 yang menunjukkan bahwa soal yang dikembangkan sesuai dengan konsep taksonomi bloom memiliki interpretasi reliabilitas tinggi. 


\subsection{Analisis Item Tes Hasil Uji Coba}

Rekapitulasi Tingkat Kesulitan (TK) Butir Soal:

Tabel 3. Tingkat Kesulitan (TK) Butir Soal Pilihan Ganda

\begin{tabular}{ccccccccccc}
\hline No. Soal & 1 & 2 & 3 & 4 & 5 & 6 & 7 & 8 & 9 & 10 \\
\hline $\begin{array}{c}\text { Index } \\
\text { Kesukaran }\end{array}$ & 0.7 & 0.6 & 0.6 & 0.9 & 0.9 & 1 & 0.7 & 0.6 & 0.6 & 0.4 \\
\hline No. Soal & 11 & 12 & 13 & 14 & 15 & 16 & 17 & 18 & & \\
\hline $\begin{array}{c}\text { Index } \\
\text { Kesukaran }\end{array}$ & 0.7 & 0.6 & 0.8 & 0.7 & 0.6 & 0.8 & 0.6 & 0.7 & & \\
\hline
\end{tabular}

Tabel 4. Tingkat Kesulitan (TK) Butir Soal Uraian

\begin{tabular}{ccccccccc}
\hline No. Soal & 1 & 2 & 3 & 4 & 5 & 6 & 7 & 8 \\
\hline $\begin{array}{c}\text { Index } \\
\text { Kesukaran }\end{array}$ & 1.7 & 2.5 & 0.8 & 2.6 & 2.9 & 2.6 & 2.3 & 2.2 \\
\hline
\end{tabular}

\subsection{Uji coba Field Test}

Selanjutnya revisi soal berdasarkan hasil analisis butir soal dan komentar/saran siswa yang terdiri dari 18 soal pilihan ganda dan 8 soal uraian yang akan diuji pada field test. Soal diselesaikan oleh siswa dalam dua kali pertemuan selama 60 menit. Pada tahap ini uji coba dilakukan pada subjek penelitian yang sesungguhnya sebagai field test yaitu siswa kelas II A SD Negeri Pajambon Kabupaten Kuningan.

Tabel 6. Nilai Siswa kelas II A SD Negeri Pajambon Kabupaten Kuningan

\begin{tabular}{cccc}
\hline No. & Subjek & Nilai & Keterangan \\
\hline 1 & A & 50.000 & Tidak Lulus \\
\hline 2 & B & 73.810 & Lulus \\
\hline 3 & C & 80.952 & Lulus \\
\hline 4 & D & 85.714 & Lulus \\
\hline 5 & E & 64.286 & Tidak Lulus \\
\hline 6 & F & 52.381 & Tidak Lulus \\
\hline 7 & G & 80.952 & Lulus \\
\hline 8 & H & 23.810 & Tidak Lulus \\
\hline 9 & I & 97.619 & Lulus \\
\hline 10 & J & 50.000 & Tidak Lulus \\
\hline 11 & K & 90.476 & Lulus \\
\hline 12 & L & 52.381 & Tidak Lulus \\
\hline & & &
\end{tabular}




\begin{tabular}{cccc}
\hline No. & Subjek & Nilai & Keterangan \\
\hline 13 & $\mathrm{M}$ & 54.762 & Tidak Lulus \\
\hline 14 & $\mathrm{~N}$ & 83.333 & Lulus \\
\hline 15 & $\mathrm{O}$ & 64.286 & Tidak Lulus \\
\hline 16 & $\mathrm{P}$ & 92.857 & Lulus \\
\hline 17 & $\mathrm{Q}$ & 80.952 & Lulus \\
\hline 18 & $\mathrm{R}$ & 69.048 & Tidak Lulus \\
\hline 19 & $\mathrm{~S}$ & 78.571 & Lulus \\
\hline 20 & $\mathrm{~T}$ & 69.048 & Tidak Lulus \\
\hline
\end{tabular}

\section{Pembahasan}

Melalui proses pengembangan soal yang terdiri dari tahap (1)menyusun spesifikasi tes (2) menulis soal tes (3) menelaah soal tes (4) memperbaiki tes (5) melakukan uji coba tes (6) menganalisis butir soal tes (7) menafsirkan hasil tes, telah menghasilkan produk soal-soal yang yang valid dan praktis yang sesuai dengan konsep Taksonomi Bloom. Soal-soal tersebut juga dinyatakan valid secara kualitatif oleh para pakar, maka selanjutnya soal-soal tersebut akan diuji validitas butirnya. Dari hasil analisis tersebut diperoleh bahwa semua soal pilihan ganda valid dengan nilai sebesar 0,81 dan soal uraian valid dengan nilai sebesar 2.04 yang berarti memiliki reliabilitas tinggi. Dari hasil ini dapat disimpulkan bahwa soal yang dikembangkan valid secara kualitatif, valid secara kuantitatif dan memiliki kriteria reliabilitas yang tinggi.

Revisi yang dilakukan menunjukkan bahwa soal yang telah dikembangkan ini praktis. Hal tersebut menandakan bahwa soal-soal yang dikembangkan sesuai konsep Taksonomi Bloom ini sesuai dengan kemampuan siswa SD, keterbacaannya baik dan soal dapat dipahami siswa. Kemudian seluruh prototype soal yang dihasilkan telah sesuai dengan indikator, kaidah penulisan soal pilihan ganda dan soal uraian yang telah melalui tahapan-tahapan proses pengembangan soal berdasarkan kurikulum sekolah dasar. Namun, memang tidak dipungkiri masih banyak bentuk soal yang bisa digali lagi oleh peneliti untuk mengembangkan kembali soal-soal ini yang sesuai konsep Taksonomi Bloom.

Berdasarkan uraian di atas maka dapat disimpulkan bahwa hasil tes soal yang telah dikembangkan berupa soal pilihan ganda yang berjumlah 18 soal dan soal uraian yang berjumlah 8 soal dapat digunakan karena terbukti valid dan praktis, dimana nilai rata-rata yang didapatkan adalah 69.76. 


\section{SIMPULAN}

Pengembangan Instrumen tes yang dihasilkan dalam penelitian ini telah memenuhi keriteria soal yang baik. Bukti bahwa instrumen tes yang dikembangkan memenuhi keriteria yang baik adalah dari hasil analisis tersebut diperoleh bahwa semua soal pilihan ganda valid dengan nilai sebesar 0,81 dan soal uraian valid dengan nilai sebesar 2.04 yang berarti memiliki reliabilitas tinggi. Hasil tes soal yang telah dikembangkan berupa soal pilihan ganda yang berjumlah 18 soal dan soal uraian yang berjumlah 8 , soal dapat digunakan karena terbukti valid dan praktis, dan menghasilkan nilai rata-rata yang didapatkan adalah 69.76 .

\section{DAFTAR PUSTAKA}

Anastasi, Anne, dan Urbina, Susana. (1997). Psychological testing. Seventh edition. Upper saddle River, Nj: Prentice Hall Inc.

Arifin, Zainal. (2012). Evaluasi Pembelajaran. Bandung: Remaja Rosdakarya.

Kunandar. (2014). Penilaian Autentik Penilaian Hasil Belajar Peserta Didik Berdasarkan Kurikulum 2013. Jakarta : Raja Grafindo Persada.

Kusaeri, K. (2014). Acuan dan Teknik proses dan Hasil Belajar dalam Kurikulum 2013. Yogyakarta: Ar-Ruqq Media.

Kusairi dan Suprananto. (2012). Pengukuran dan Penilaian Pendidikan. Yogyakarta: Graha Ilmu.

Mardapi, D. (2008). Teknik Penyusunan Instrumen Tes dan Non Tes. Yogyakarta: Mitra Cendekia.

Purwanto. (2013). Evaluasi Hasil Belajar. Yogyakarta: Pustaka Belajar.

Thorndike, Robert L dan Hagen, Elizabeth P. (1977). Measurement and evaluation in psychology and education. $4^{\text {th }}$ edition. New York: Jhon Wiley \& Sons.

Undang-Undang Republik Indonesia Nomor 20 Pasal 1 tahun 2003: Sistem Pendidikan Nasional. 